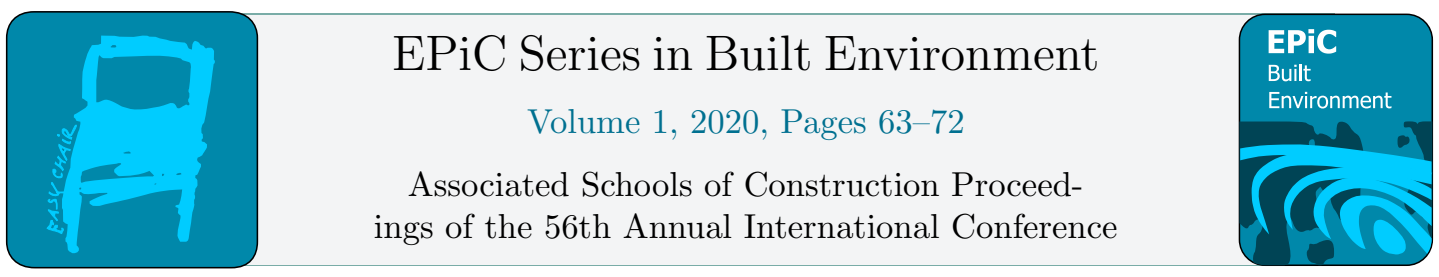

\title{
Exploratory Study of MBAs With a Technical Specializations in Construction and Project Management
}

\author{
Sherif Attallah Ph.D. and James Jones Ph.D. and Mathew Simpson R.A. \\ Ball State University, Muncie, Indiana \\ soattallag@bsu.com, jimwjones@bsu.edu, mdsimpson2@bsu.edu
}

\begin{abstract}
There is an absence of data in the available literature on the current status of programs that offer an MBA with a technical specialization. This study addresses that absence of data with an overall discussion of MBA specializations and an investigation of MBAs that offer a technical specialization in construction management (CM) and project management (PM). Information on programs that offer $\mathrm{CM}$ or PM technical specializations was collected using a university's official website, as well as, phone conversations with personnel. A total of 39 of 368 MBA programs offered the CM and/or PM technical specialization. These programs were analyzed across multiple data points such as cost, courses, and time to completion. Data collected on the availability of MBAs with a technical specialization in either CM or PM revealed that both curriculums are virtually nonexistent across academia. Universities that begin to offer PM or CM technical specializations will be filling a current knowledge gap that will benefit both students and employers alike. Further research into the degree that employers prefer technical specialization is needed. The data collected in this study indicate that there are still areas of study that MBA programs can address with the introduction of new technical specializations.
\end{abstract}

\section{Introduction}

According to (Hunt and Speck, 1986), during the 1960's, the MBA received a makeover that resulted in universities moving away from specialized MBAs and toward a broad foundation. The new look MBA focused on principles, analysis and problem solving. This broad approach led to an MBA revolution where schools saw the number of MBA's granted increase from under 5,000 in 1960 to over 63,000 by the early 80 's (Hunt and Speck, 1986). The multipurpose approach to the MBA's was a success. However, an examination of 27 of the top MBA programs in 1986 by Hunt and Speck showed that another shift had occurred. The authors were not able to find any evidence that MBA programs were currently offering the broad MBA (Hunt and Speck, 1986). A return to the specialized MBA had occurred. Through a detailed survey Hunt and Speck determined that most employers prefer some level of technical specialization. A survey of fortune 500 companies showed that $75 \%$ of 
Exploratory Study of MBAs With Technical Specializations in Construction and ... S. Attallah et al.

the companies that replied (157 of 457) prefer some level of technical specialization. The degree of technical specialization that was preferred was 3 to 4 classes of a specific focus area. However, these results have been recently countered, as (Gupta et al., 2007) found significantly different results.

(Gupta et al. 2007) investigated the MBA in a similar fashion to Hunt and Speck. The authors set out to examine the current trend with respect to the broad MBA versus an MBA with a technical specialization. Their study looked at 758 employment advertisements and cited that only $5 \%$ required an MBA. The remaining 95\% preferred that the applicant possesses an MBA, but did not require it. Companies that preferred an MBA technical specialization constituted $4 \%$ of all advertisements studied. (Gupta et al., 2007) revisited the 27 MBA programs analyzed by Hunt and Speck and found that they still offer technical specializations and have increased the amount of technical specializations offered. Their conclusion was that there is a disconnect between employers and schools, resulting in a gap between the offering of a technical specialization versus a business requiring one. (Gupta et al., 2007) stated that there is a need for further research into the needs of employers. A survey to establish if the content in the advertisements reflect what employers are looking for in an applicant would be a key data point to uncover. While the data does call into question the findings of Hunt and Speck, there are some glaring issues with their methods.

Based on this authors' experience in business management, employers create advertisements to draw in a wide breadth of applicants. An employer that requires an MBA immediately eliminates someone that has 20 years of work experience but lacks the degree requirement. Along the same thought process, if an employer requires a technical specialization, they remove all general MBA's thus eliminating an applicant that might be far better suited for the job. By not requiring a specific degree they increase the likelihood of finding the right employee for the job. This inclusive approach to hiring practices does not negate the advantages of a technical specialization. A prospective applicant with a technical specialization in international business is still going to have an increased likelihood of employment as a management analyst versus an applicant with a broad MBA. The technical specialization might not be on the advertisement, but any employers looking at prospective applicants will be placing those with technical specializations in their field at the top of the recruitment pile.

According to (Tan and Ko, 2019), an applicant with a technical specialization is signaling to a potential employer that they have a higher competency in a given area, as well as, a willingness to go one step further than other applicants with a broad MBA. Students seem to recognize this factor based on their desire to include a technical specialization in their degree. Ninety percent of students in a poll conducted by (Gupta et al., 2007) would register for a technical specialization if it was offered. While there is still some debate over which degree a prospective student should pursue, a specialized MBA could give students an advantage over their competition. Therefore, the objective of this paper is to shed light on the lack of literature on MBAs that offer a technical specialization. An investigation of the current status of MBAs that offer a specific focus on construction and project management will offer new insight into this issue.

\section{MBA Technical Specializations}

Over the past three decades, MBA programs have continued to move toward a specialized education. The majority of MBA programs analyzed in this article offer some form of technical specialization either through a concentration or a tailoring of the degree. The more common technical specializations include finance, accounting, general management, marketing, and entrepreneurship. These technical specializations reflect some of the core areas that the creation of broad MBA added to 
Exploratory Study of MBAs With Technical Specializations in Construction and ... S. Attallah et al.

the curriculum in the 1960s (Hunt and Speck, 1986). A technical specialization is often a focused study of a subject that is found within the core offerings within the MBA. Among 27 selected universities there were a total of 85 niche technical specialization offered (Gupta et al., 2007). Project management and construction management are two of these niche technical specializations.

Construction management and project management are underrepresented amongst universities offering MBAs. A recent survey of 1555 civil engineers, and architects, found that just short of $80 \%$ stated that they were sufficiently lacking in multiple areas of construction management (Ayalp, 2016). There is a clear desire for these programs. Anyone working on the business side of construction, and lacking a CM degree, would benefit from a CM technical specialization. A vast majority of these employees understand the technical side of their job yet lack the management skills required to excel at their position. Even if an individual has spent some time attaining on the job experience, they could still be lacking the specific knowledge that could be provided in a CM or PM technical specialization. According to (Sampietro and Nieto-Rodriguez, 2016), most students coming into a project management program lack the basic understanding of how to lead projects irrespective of their background. While experience is always good, having guidance with practice can still lead to a deeper understanding.

Universities are incentivized to develop programs that will attract students (Bisoux, 2005). Therefore, developing technical specializations that fill a knowledge gap is key and could be a benefit to both students and universities. Project management contents was found in 81 of $180 \mathrm{MBA}$ programs examined (Sampietro and Nieto-Rodriguez, 2016). However only $6 \%$ of those same schools offer technical specializations in project management. This is an area that has clear room for growth due to the prevalence of project management across multiple business fields.

There is a near complete absence of literature on construction management technical specializations. Literature investigating the current state of MBA's and technical specializations is equally limited. An investigation of 368 current MBA programs was conducted to attempt to fill this gap in the information with respect to a CM or PM technical specialization. The data points were selected to inform interested parties on the financial, time, and availability as of the time this research was conducted.

\section{Method}

Universities with MBA programs were found using the MBA.com data base. Data was primarily collected from program websites. Phone conversation were conducted with three programs where the data required was unavailable, or not clearly stated on their website. Program availability, courses offered, time to finish, and cost per credit hour were among the areas that were analyzed. A total of 368 programs were analyzed beginning with MBAs offered within the state of Indiana and then broadening the search to include the continental United States. The selection of programs was based on non-probability sampling due to the large amount of programs providing technical specializations. 


\section{Results}

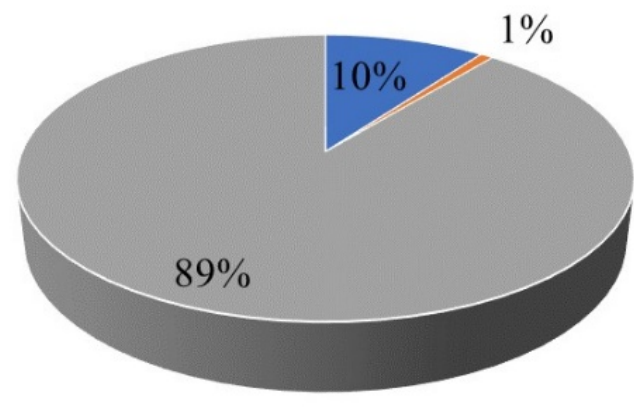

\section{- $\mathrm{PM} \approx \mathrm{CM} \approx \mathrm{No} \mathrm{PM} / \mathrm{CM}$}

Figure 1: Availability of CM/PM Specialization

This section presents the results of the analysis done with a focus on availability, cost, courses offered, and time to completion for CM and PM technical specializations. Figure 1 shows that a project management technical specialization is offered in 39 of the 368 programs analyzed. The construction management technical specialization was found in only 3 programs. The cost per hour was analyzed across all 39 schools that offered the PM or CM technical specialization. Figure 2

displays the of costs per credit hour with the median cost being $\$ 844.46$ and with a range of $\$ 1425.00$.

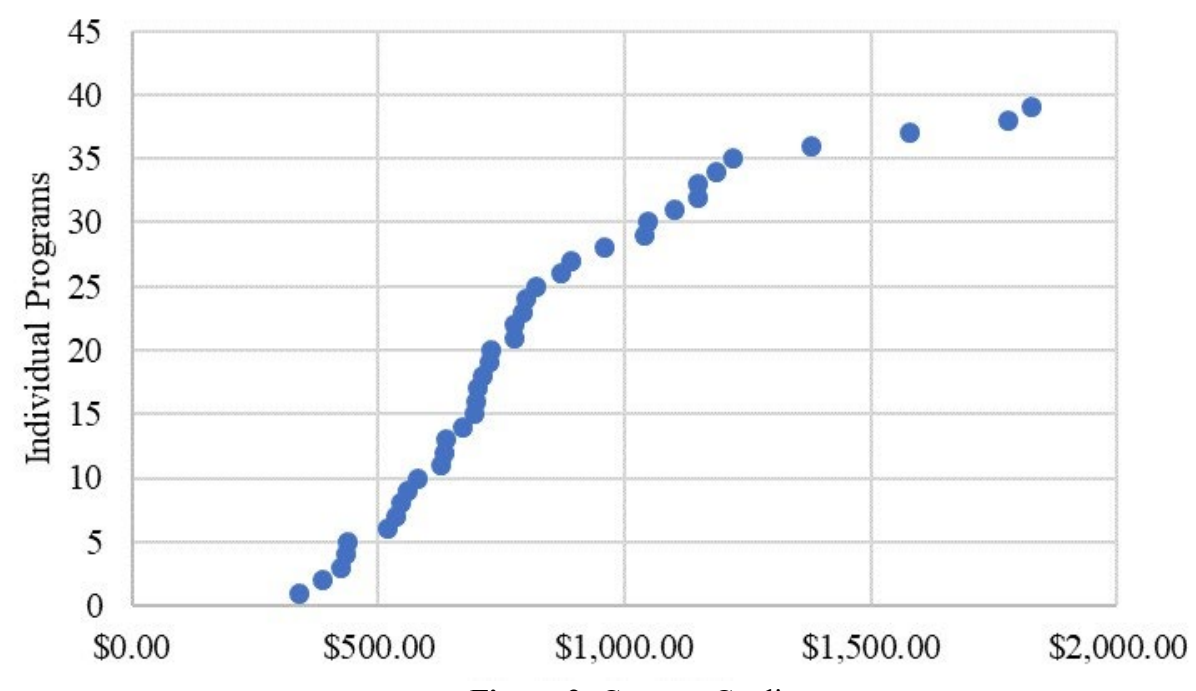

Figure 2: Cost per Credit 


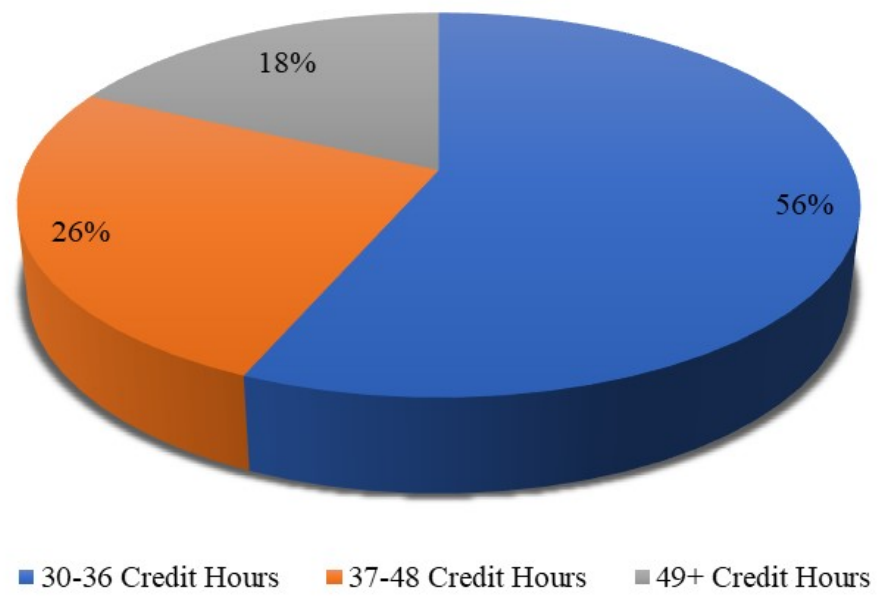

Figure 3: Credit Hours Required for Graduation

The credit hours required by each university had a mode of 36 and range of 46 . Figure 3 illustrates that most programs in the study are requiring 36 credit hours or less for a student to complete their MBA. The credits required for the PM/CM technical specialization is included in the total credit hours required.

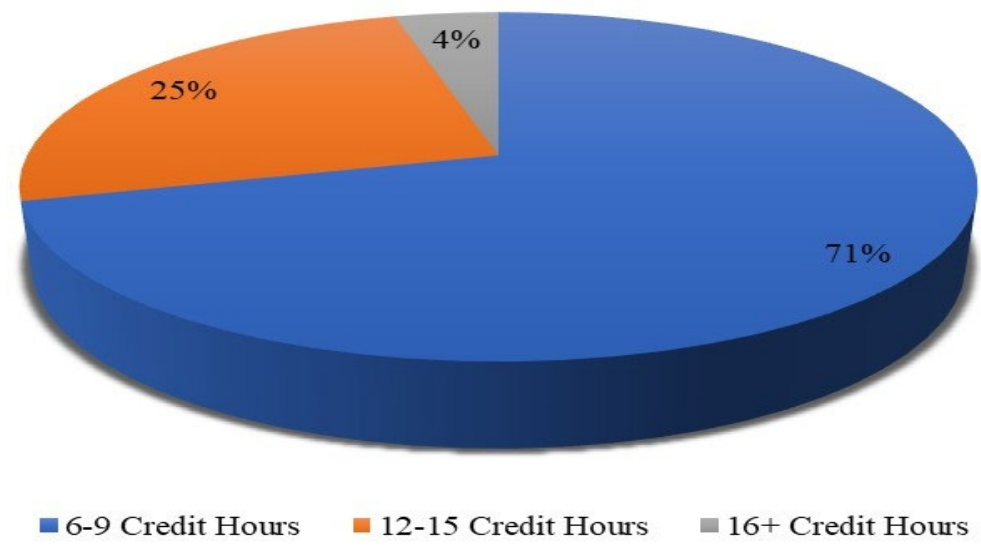

Figure 4: Credit Hours Toward Specialization

Figure 4 confirms that programs overwhelmingly allot 6 to 9 credit hours toward a technical specialization versus $12-15$ and 16 plus. A single program allotted 24 credit hours of their 36 total credit hours toward a technical specialization.

Analyzing the curriculums of MBA's core classes show a significant amount of crossover between programs. However, this is not the case when analyzing classes required for a $\mathrm{PM} / \mathrm{CM}$ technical specialization. A total of 27 of 39 programs listed their PM/CM technical specialization courses on their website. The courses were far more varied than general MBAs. The 27 curriculums 
Exploratory Study of MBAs With Technical Specializations in Construction and ... S. Attallah et al.

offered a total of 113 courses. After removing courses that were clearly similar based on title the remaining 85 courses can be found on Table 1 .

\begin{tabular}{|c|c|c|}
\hline \multicolumn{3}{|l|}{ Table 1} \\
\hline \multicolumn{3}{|c|}{ CM/PM Graduate Courses Offered } \\
\hline $\begin{array}{l}\text { Project Management } \\
\text { Fundamentals and Best } \\
\text { Practices }\end{array}$ & $\begin{array}{l}\text { Project Procurement and Risk } \\
\text { Management in Projects }\end{array}$ & $\begin{array}{l}\text { Project Management Standard } \\
\text { Processes }\end{array}$ \\
\hline $\begin{array}{l}\text { Managing Organizational } \\
\text { Change and Innovation }\end{array}$ & $\begin{array}{l}\text { Seminar in Quality and } \\
\text { Performance Management }\end{array}$ & $\begin{array}{l}\text { Program and Project Portfolio } \\
\text { Management }\end{array}$ \\
\hline $\begin{array}{l}\text { Negotiation and Interpersonal } \\
\text { Skills for Managers }\end{array}$ & $\begin{array}{l}\text { Contract Management and } \\
\text { Ethics }\end{array}$ & Supply Chain Management \\
\hline $\begin{array}{l}\text { Project Planning and Control } \\
\text { Techniques Strategic Issues - } \\
\text { The PMO }\end{array}$ & $\begin{array}{l}\text { Cases in Applied Project } \\
\text { Management }\end{array}$ & Leadership and Team Building \\
\hline $\begin{array}{l}\text { Strategic Project Selection and } \\
\text { Initiation }\end{array}$ & $\begin{array}{l}\text { Project Planning and the } \\
\text { Project Plan }\end{array}$ & $\begin{array}{l}\text { Project Execution with } \\
\text { Monitoring and Control }\end{array}$ \\
\hline $\begin{array}{l}\text { Project Closing, Ethics, and } \\
\text { Professional Responsibilities }\end{array}$ & $\begin{array}{l}\text { Project Schedule and Risk } \\
\text { Management Cost }\end{array}$ & $\begin{array}{l}\text { Contract and Procurement } \\
\text { Management }\end{array}$ \\
\hline $\begin{array}{l}\text { Project Management: } \\
\text { Planning, Scheduling, and } \\
\text { Control Project Portfolio } \\
\text { Management }\end{array}$ & Human Resource Management & $\begin{array}{l}\text { Project Management } \\
\text { Externship }\end{array}$ \\
\hline $\begin{array}{l}\text { Advanced Project } \\
\text { Management }\end{array}$ & Global Project Management & $\begin{array}{l}\text { Project Management: } \\
\text { Integration, Scope, Time, and } \\
\text { Communication }\end{array}$ \\
\hline $\begin{array}{l}\text { Project Planning, Execution } \\
\text { and Closure }\end{array}$ & $\begin{array}{l}\text { Quality Management and } \\
\text { Continuous Improvement }\end{array}$ & Topics in Project Management \\
\hline Quality Issues in Operations & $\begin{array}{l}\text { Disaster Recovery and } \\
\text { Business Continuity }\end{array}$ & Applied Project Management \\
\hline Management & Sustainable Management & Risk and Budget Management \\
\hline Procurement and Contract & $\begin{array}{l}\text { Advanced Project/Portfolio } \\
\text { Management }\end{array}$ & Project Analysis and Control \\
\hline Project Management Capstone & $\begin{array}{l}\text { Introduction to Project } \\
\text { Management }\end{array}$ & $\begin{array}{l}\text { Contract \& Procurement } \\
\text { Management }\end{array}$ \\
\hline $\begin{array}{l}\text { Leading Projects Across } \\
\text { Cultural, Corporate, \& Global } \\
\text { Boundaries }\end{array}$ & Process and Methodology & $\begin{array}{l}\text { Project Cost and Schedule } \\
\text { Control }\end{array}$ \\
\hline Project Simulation & $\begin{array}{l}\text { Project Execution and Control } \\
\text { MBA }\end{array}$ & Project Portfolio Management \\
\hline Leadership of Project Teams & Principles of Six Sigma & Strategic Outsourcing \\
\hline $\begin{array}{l}\text { Tools and Techniques of the } \\
\text { Project Management }\end{array}$ & Organizational Behavior & Open Book Management \\
\hline $\begin{array}{l}\text { Management in Healthcare } \\
\text { Organizations }\end{array}$ & Executive Development & $\begin{array}{l}\text { Topics in Management and } \\
\text { Leadership }\end{array}$ \\
\hline Topics in Management & $\begin{array}{l}\text { Readings in Management and } \\
\text { Leadership }\end{array}$ & $\begin{array}{l}\text { Additional Readings in } \\
\text { Entrepreneurship }\end{array}$ \\
\hline
\end{tabular}


Exploratory Study of MBAs With Technical Specializations in Construction and ... S. Attallah et al.

\begin{tabular}{|l|l|l|}
\hline Entrepreneurship & Topics in Entrepreneurship & $\begin{array}{l}\text { International Business } \\
\text { Administration }\end{array}$ \\
\hline $\begin{array}{l}\text { Topics in International } \\
\text { Business }\end{array}$ & $\begin{array}{l}\text { Readings in International } \\
\text { Business }\end{array}$ & $\begin{array}{l}\text { Topics in Advanced } \\
\text { Technology }\end{array}$ \\
\hline $\begin{array}{l}\text { Readings in Management } \\
\text { Information Systems }\end{array}$ & $\begin{array}{l}\text { Productivity Software for } \\
\text { Managers }\end{array}$ & $\begin{array}{l}\text { Data Communications for } \\
\text { Managers }\end{array}$ \\
\hline $\begin{array}{l}\text { Managing Systems } \\
\text { Development }\end{array}$ & Electronic Commerce & $\begin{array}{l}\text { Complex Issues in Project } \\
\text { Management }\end{array}$ \\
\hline Managing Outsourced Projects & Agile Project Management & $\begin{array}{l}\text { Organization Development and } \\
\text { Change Management }\end{array}$ \\
\hline Managing a Global Workforce & $\begin{array}{l}\text { Entrepreneurship and New } \\
\text { Venture Management }\end{array}$ & $\begin{array}{l}\text { Project Planning Evaluation } \\
\text { and Control Techniques }\end{array}$ \\
\hline Cost and Value Management & $\begin{array}{l}\text { Planning and Resource } \\
\text { Management }\end{array}$ & $\begin{array}{l}\text { Commercial Law and Project } \\
\text { Procurement }\end{array}$ \\
\hline $\begin{array}{l}\text { Strategies for Effective } \\
\text { Negotiation }\end{array}$ & $\begin{array}{l}\text { Agile Project Management } \\
\text { Techniques for Iterative }\end{array}$ & $\begin{array}{l}\text { Effective Meeting } \\
\text { Management and Facilitation }\end{array}$ \\
\hline $\begin{array}{l}\text { How to Influence Without } \\
\text { Direct Authority }\end{array}$ & Managing Project Risks & $\begin{array}{l}\text { Project Leadership } \\
\text { Communication }\end{array}$ \\
\hline
\end{tabular}


Exploratory Study of MBAs With Technical Specializations in Construction and ... S. Attallah et al.

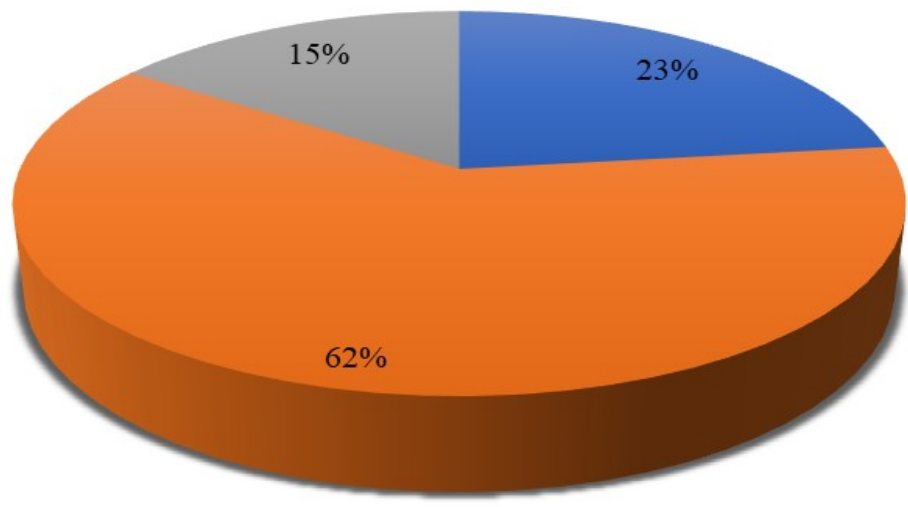

घ-18 Months $\approx 24$ Months $\amalg 24+$ Months

Figure 5: Time to Graduate

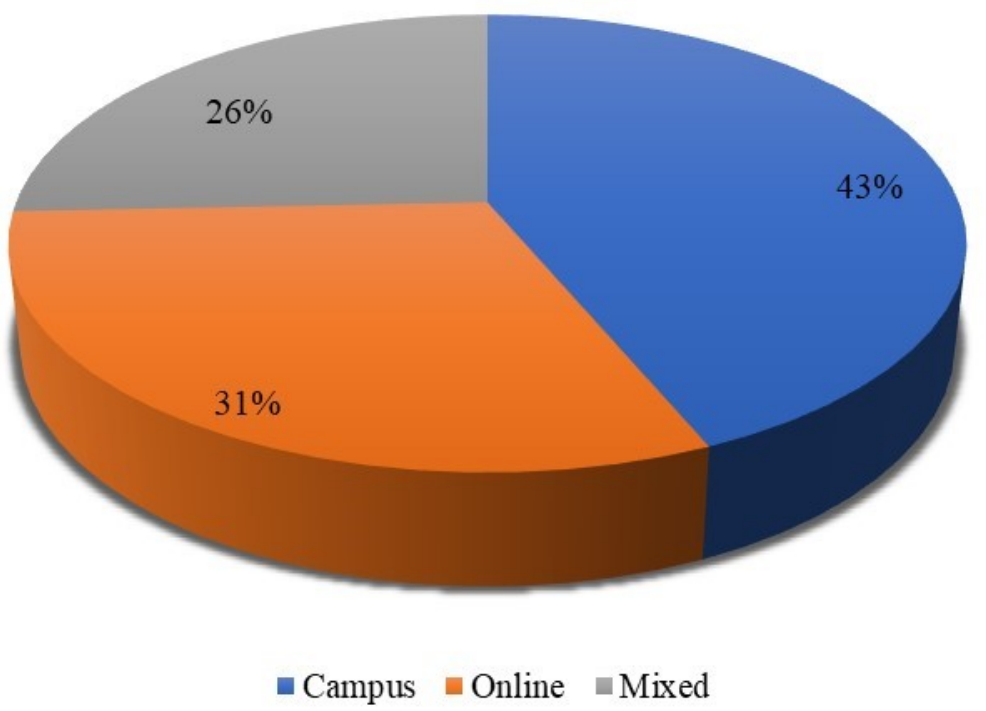

Figure 6: Setting of Degree

Figure 5 reveals that Twenty-three percent of the programs offer the student the opportunity to be completed in 18 months or less. Sixty-seven percent of the 18 month or less programs are offered either strictly online or mixed. The remaining programs are 18-month MBAs and offered only on campus. Figure 6 establishes that the campus setting is still the most prevalent amongst the programs offering the $\mathrm{PM} / \mathrm{CM}$ technical specialization. This statistic is made stronger when you group mixed and campus together to represent $69 \%$ of the programs analyzed. 
Exploratory Study of MBAs With Technical Specializations in Construction and ... S. Attallah et al.

\section{Discussion}

$\mathrm{PM} / \mathrm{CM}$ specializations are woefully underrepresented based on the programs that were analyzed. This absence could be in part due to the lack of literature reviewing the current needs of employers in those potential areas of work. This study found only three peer reviewed articles published within the last five years that looked at MBAs and/or PM/CM specializations offerings in any capacity. The only other journal offering is over a decade old.

Based on the data collected, the degree can be attained from an accredited university for as little as $\$ 12,240.00$. There are degrees that are substantially more expensive, totaling over $\$ 85,000$ for a two-year degree. For many of the programs analyzed, a student would spend $\$ 12,000$ to $\$ 25,000$ to attain a degree. The price for an MBA is sighted as a factor for students choosing to attain the degree (Choi et al., 2019). However, there are multiple factors being considered by prospective students. The length to complete as well as the focus of the degree is also a priority.

A standard within MBA curriculum on the range of credit hours and courses required to complete an MBA with a technical specialization does not exist. This lack of standard could be universities trying to separate themselves from other universities by offering what they believe are attractive courses. The courses offered across the multiple PM/CM technical specializations cover a large area of study. The amount of variance in the courses offered are significant enough that a student could focus their technical specialization even further by completing an intense review of all the courses offered. The competition to acquire new students is fierce and this alone could be responsible for the variety of MBA designs available (Bisoux, 2005). A program offering a technical specialization in PM with courses such as Introduction to Project Management, Advanced Project Management, and Tools and Techniques of Project Management could seem mundane. Schools offering courses such as Entrepreneurship, New Venture Management, Negotiation and Interpersonal Skills for Managers, and Leading Projects Across Cultural, Corporate, \& Global Boundaries could garner students based on the uniqueness of the courses. This could be compounded by most MBAs already offering at least one general course in project management (Sampietro and Nieto-Rodriguez, 2016). A prospective student might be more inclined to apply to a university offering unique courses in project management versus a general course.

A 24-month MBA is the clear standard amongst universities, yet there is still a small degree of variance. The variance appears to be a function of the setting of the MBA. The setting being campus, online, or mixed. Online MBAs offered the shortest completion time, with one program stating completion could be attained in as little as 8 months. Among the campus and mixed settings an 18 month completion time was the shortest available.

\section{Conclusion and Outlook}

The most significant finding was the limited number of offerings in construction management in both the available literature and technical specializations. Project management was offered in $10 \%$ of the schools analyzed, while construction management was less than $1 \%$. This area of technical specialization has a significant amount of room to grow. The technical specialization allows current employees to fill in a knowledge gap in order to advance within their company. An example would be a field geologist that wishes to be considered for a project management position but lacks the business acumen required. In the construction industry, there are numerous employees with degrees focusing on accounting, financing, etc. that could benefit from attaining a CM technical specialization. Overall, the technical specialization still has a strong foothold in academia, but further 
Exploratory Study of MBAs With Technical Specializations in Construction and ... S. Attallah et al.

research is needed to establish if technical specializations are still as sought after as they were in 1986.

While the data collected focused on specific technical specializations the research conducted provides a need for establishing the current validity of MBA programs and the ability to meet the needs of employers. This research could be accomplished through a survey similar to Hunt and Speck (1986). Expanding the survey to include questions addressing specific skills that employers believe graduates are lacking would be benefit program providers and students.

\section{References}

Ayalp, G., Öcal, M., (2016) Determining Construction Management Education Qualifications and the Effects of Construction Management Education Deficiencies on Turkish Construction. Creative Education, 7(1), 254-268.

Bisoux, T. (2005, May/June). The Extreme MBA Makeover. BizEd, pp. 27-33.

Boon Seng Tan \& Stephen Ko (2019). How Relevant is the MBA: A revisit. Journal of Education for Business, 94(1), 64-69. DOI: 10.1080/08832323.2018.1503587

Choi P., Harris M., Ernstberger, K., Cox, C., \& Musgrove C., (2019). An Exploratory Study on Parttime MBA Program Choice Factors and Characteristics of Part-time MBA Students. Journal of Education for Business, 94(3), 139-147. DOI: 10.1080/08832323.2018.1491823

Gupta P., Saunders, P., \& Smith, J., (2007). Traditional Master of Business Administration (MBA) Versus the MBA With Technical specialization: A Disconnection Between What Business Schools Offer and What Employers Seek. Journal of Education for Business, 82(6), 307-312, DOI: $10.3200 / J O E B .82 .6 .307-312$

Hunt, S. D., \& Speck, P. S. (1986). Technical specialization and the MBA: Is the broad MBA passé?. California Management Review, 29(3), 159-175.

Sampietro M., Nieto-Rodriguez, A., (2018). Project Management at Top Business Schools. Project Management Development-Practice and Perspectives, 7, 84-102. 